\title{
Evaluasi Produksi dan Kualitas Nutrisi pada Bagian Daun dan Kulit Kayu Calliandra callotirsus dan Gliricidia sepium
}

\author{
D. R. A. Daning ${ }^{*}$, B. Foekh \\ Sekolah Tinggi Penyuluhan Pertanian Malang
}

\begin{abstract}
ABSTRAK
Penelitian ini bertujuan untuk mengetahui kecernaan bahan kering dan bahan organik bagian tanaman berbeda dari Kaliandra dan Gamal yang diuji secara in vitro. Peubah yang diamati meliputi data produksi segar pada bagian tanaman kaliandra dan gamal, diameter dan panjang ranting tanaman kaliandra, analisis proksimat, Kecernaan Bahan Kering (KcBK) dan Bahan Organik (KcBO). Data yang diperoleh dilakukan pengujian independent sample t-test. Hasil penelitian menunjukkan bahwa data produksi daun, batang, dan kulit batang kayu pada tanaman Kaliandra dan Gamal tidak ada perbedaan yang nyata $(\mathrm{P}>0,05)$, akan tetapi panjang batang dan diameter batang antara Gamal berbeda nyata $(\mathrm{P}>0,05)$ dibandingkan Kaliandra, selanjutnya untuk mengetahui kualitas nutrisi dan kecernaan bagian tanaman dilakukan pengujian di Laboratorium Biokimia Nutrisi, Fakultas Peternakan, UGM. Hasil analisis menunjukkan bahwa kualitas nutrisi bagian daun dan kulit batang tanaman kaliandra dan gamal juga tidak ada perbedaan, akan tetapi nilai kecernaan bahan kering dan bahan organik bagian kulit kayu lebih tinggi dibandingkan bagian daun. Selanjutnya dari hasil produksi tanaman dapat disimpulkan bahwa kedua tanaman tersebut tidak berbeda nyata untuk produksinya, akan tetapi diameter batang lebih besar tanaman gamal dibandingkan tanaman kaliandra.
\end{abstract}

Kata Kunci: Bagian morphologi, Calliandra dan Gliricidia, Bahan organik, Penguraian Rumen, Produksi gas in vitro

\section{Evalluation of Production and Nutrient Qualityon Parts of Leaves and Bark Wood Calliandra callotirsus and Gliricidia sepium}

\begin{abstract}
The aim of our study was to determine the nutrient content and organic matter degradability of different morphological parts (leaves and bark wood) of Calliandra and Gliricidia. Variable observations were fresh production of leaves and bark wood, diameter and length of plant, proximate analysis, degradability of dry and organic matter. Data was analyzed by independent sample t-test. The results showed that data prodoction of leaves, stems, bark wood on the plant Kaliandra and Gamal was not significant differences (P>0.05), but the diameter and length of rod between Gamal significantly different $(P>0.05)$ compared to Kaliandra, furthermore to know nutritional quality and degradability is tested at the Laboratory of Biochemistry Nutrition, Faculty of Animal Science, UGM. The analysis showed that the nutritional quality of the leaves and bark wood of plants Calliandra and Gamal was also no difference, but the value of dry matter and organic matter part of the bark was higher than the leaves.Furthermore, from crop production can be concluded that the both of plant are not significantly different for the data production, but a diameter of gamal steam greater than kaliandra.
\end{abstract}

Keywords: Morphological parts, Calliandra and Gliricidia, Organic matter; Rumen degradability, In vitro gas production method

\section{PENDAHULUAN}

Tanaman Legum merupakan tanaman yang biasanya digunakan untuk pakan ternak ruminansia dan juga non ruminansia. Legum ini memiliki kandungan protein yang sangat tinggi, karena memiliki perakaran yang banyak mengandung air, legume merupakan tanaman pakan yang sangat penting bagi ternak karena kaya kandungan nutrisi untuk memenuhi kebutuhan ternak. Indonesia merupakan daerah tropis yang memiliki keayaan jenis tanaman pakan yang beragam, salah satunya Kaliandra dan Gamal. Calliandra and Gliricidia memiliki karakteristik kandungan protein yang tinggi, sehingga mampu mencukupi kebutuhan pokok nutrisi ternak. Morfologi pada bagian tanaman legume memiliki kandungan nutrisi yang berbeda pada setiap

\footnotetext{
*Penulis Korespondensi: D. R. A. Daning

Alamat: Jl. DR. Cipto No.144a, Bedali, Lawang, Malang, Jawa Timur

E-mail: daningstpp@gmail.com
}

bagiannya,. Pada bagian vegetative tanaman mengandung $70 \%$ komponen bahan kering dari total tanaman, sehingga akan berpengaruh juga terhadap kualitas hijauan dari legume (Elevitch and Francis, 2006).

Kaliandra termasuk salah satu tanaman legume yang sangat penting bagi ternak ruminansia pada daerah tropis karena termasuk tanaman yang tumbuh dengan cepat dan baik, meskipun pada kondisi tanah yang buruk. Kaliandra merupakan tanaman yang mempunyai bentuk berupa pohon kecil atau perdu yang termasuk kedalam keluarga leguminosa (Mulyana et al., 2006). Sebagian besar peneliti melaporkan bahwa kaliandra dalam keadaan segar sangat palatable untuk ternak, meskipun tidak mengalami masa adaptasi pakan (Karda, 2011). Kalindra juga merupakan sumber protein ternak sebesar 31,35\% (Novia et al., 2015), meskipun demikian Tangendjaja et al. (1992) melaporkan bahwa kandungan tannin sebesar 1,5-11,3\% pada kaliandra menyebabkan tingkat kecernaan rendah 
sebesar 30-60\%. Hasil penelitian Salawu et al. (1999) juga menjelaskan bahwa kecernaan protein secara in vitro pada bagian daun dan biji kaliandra memiliki perbedaan yang signifikan, hal ini dikarenakan kandungan tannin setiap bagian tanaman kaliandra juga berbeda.

Tanaman legume yang sangat penting bagi ternak selain kaliandra yaitu gamal (Gliricidia sepium) karena tanaman yang cepat tumbuh, mampu mengikat nitrogen, sumber kayu bakar, pohon naungan dan tiang bangunan (Natalia et al., 2009). Produksi gamal yang dilakukan setiap 3 bulan sekali menghasilkan produksi sebanyak 32,50 ton/ha/tahun (Wong, 2012). Berdasarkan Orskov (2000), evaluasi pakan sangat penting bagi peternak dalam hal perencanaan penanaman tanaman pakan, sehingga memberikan informasi untuk menentukan tanaman yang terbaik untuk ternak. Teknik in vitro pada laboratorium merupakan teknik untuk menentukan estimasi degradasi pakan mendekati kecernaan dan metabolisme energi untuk ternak ruminansia (Menke et al., 1988). Teknik gas tes banyak diminati oleh peneliti karena dapat diketahui degradasi pakan melaui pengukuran volume setiap waktu untuk satu jenis sample (Orskov, 1992). Hasil penelitian Mei et al. (2013) menjelaskan bahwa komposisi rasio produksi gamal berkisar $72-76 \%$ bagian daun dan $24-$ $28 \%$ bagian ranting, akan tetapi proporsi ini akan mengalami perubahan seiring peningkatan umur gamal. Penurunan proporsi daun dan ranting akan berhubungan dengan peningkatan kandungan dinding sel (Djuned et al., 2005). Menurut Hartadi et al. (1993) kandungan nutrisi gamal 25\%, Elevith dan Franchis (2006) 18-24\%), Natalia et al. (2009) 20$30 \%$ dan Mei et al. (2013) 24,28\%-25,98\%. Kandungan nutrient yang sangat tinggi pada gamal sangat cocok untuk suplemen pada hijauan berkualitas rendah, akan tetapi kualitas nutrisi pada gamal memiliki kandungan yang berbeda pada setiap bagian tanamnnya (Andrew, 1994). Tujuan dari penelitian ini adalah untuk mengetahui kandungan nutrisi dan kecernaan kaliandra dan gamal pada bagian tanaman yang berbeda dengan teknik in vitro gas tes.

\section{MATERI DAN METODE}

\section{Persiapan Sampel Kaliandra dan Gamal}

Kaliandra dan gamal merupakan tanaman koleksi dari kebun Laboratorium Nutrisi dan Makanan Ternak, Sekolah Tinggi Penyuluhan Pertanian Malang. Lokasi yang terletak pada altitude $456 \mathrm{~m}$ diatas laut, 112 06' lintang selatan, 7,06' lintang timur, Temperatur: $22,7-25,1$ max: $32,7^{\circ} \mathrm{C}$, kelembaban $79-85 \%$, jenis tanah inceptisol, serta ratarata curah hujan sebesar $1100 \mathrm{~mm}$. Tanaman berumur 5 tahun dan periode pemangkasan setiap 14 minggu/56 hari. Pemotongan tanaman dilakukan menggunakan gunting pada bagian tanaman pangkalnya, ranting dengan tinggi potong $100 \mathrm{~cm}$ dari tanah dan $717 \mathrm{~cm}$ dari percabangan. Hasil pemotongan ditimbang dengan berat segar dan selanjutnya dipisahkan antara daun dan batang kemudian ditimbang lagi sebagai data produksi segar. Tanaman dipisahkan antara daun dan kulit batangnya untuk mempersiapkan sampel yang selanjutnya dijemur hingga kondisi kering udara. Semua sampel digiling menggunakan alat hummer meal dengan screen $1 \mathrm{~mm}^{2}$, tepung daun dan batang kayu selanjutnya dianalisis kandungan nutrisi dan kecernaan secara in vitro di Laboratorium Biokimia Nutrisi, Fakultas Peternakan, Universitas Gadjah Mada.

\section{Produksi Gas In Vitro}

Sampel diinkubasi in vitro berdasarkan metode Menke et al. (1988) yang dimodifi kasi oleh Blümmel et al. (1997). Sebanyak $300 \mathrm{mg}$ sampel diinkubasikan ke dalam medium berupa cairan rumen-buffer. Cairan rumen diambil pada pagi hari dari sapi friesian holstein berfi stula sebelum diberi pakan. Setelah koleksi, cairan rumen dibawa ke laboratorium, disaring dengan saringan nilon berukuran $100 \mu \mathrm{m}$,dan ditambah buffer tereduksi. Rumen-buffer dijenuhkan dengan gas $\mathrm{CO}_{2}$ selama 10 menit sebelum dimasukkan ke dalam tabung syringe untuk menjamin kondisi anaerob dalam reaksi. Sampel dimasukkan ke dalam tabung dan ditutup dengan piston yang telah dilubrikasi oleh vaselin. Sebanyak $30 \mathrm{ml}$ cairan rumen-buffer dimasukkan ke dalam masing-masing tabung melalui saluran inlet, kemudian tabung segera dimasukkan ke dalam water bath bersuhu $39^{\circ} \mathrm{C}$. Produksi gas diamati pada jam ke-0, 3, 6, 12, 48 setelah dilakukan inkubasi, selanjutnya sample hasil inkubasi disaring dan dianalisis bahan kering dan bahan organik untuk diamati kecernaan bahan kering dan bahan organik.

\section{Peubah yang Diamati}

Peubah yang diamati meliputi data produksi segar pada bagian tanaman kaliandra dan gamal, diameter dan panjang ranting tanaman kaliandra, analisis proksimat (AOAC, 1990), Kecernaan Bahan Kering $(\mathrm{KcBK})$ dan Bahan Organik $(\mathrm{KcBO})$. Data yang diperoleh dilakukan pengujian independent sample $t$-test.

\section{HASIL DAN PEMBAHASAN}

\section{Produksi Daun Dan Kulit Batang Kayu Selama Pemanenan}

Hasil panen untuk setiap 56 hari dipisahkan antara daun dan batang yang besarnya masing-masing dapat dilihat pada Tabel 1. Hasil pengamatan menunjukkan bahwa produksi segar ( $\mathrm{Kg} /$ pohon) kaliandra dan gamal pada bagian yang berbeda tidak memiliki perbedaan yang tidak nyata $\mathrm{P}>0,05$. Selanjutnya dari hasil pengamatan juga diketahui bahwa diameter cabang tanaman kaliandra lebih kecil dibandingkan gamal $(\mathrm{P}<0,05)$, akan tetapi panjang cabang dari kedua tanaman ini tidak berbeda nyata. 
Tabel 1. Produksi segar kaliandra dan gamal pada bagian tanaman yang berbeda

\begin{tabular}{|c|c|c|}
\hline \multirow{2}{*}{ Produksi Segar } & \multicolumn{2}{|r|}{ Jenis tanaman } \\
\hline & Kaliandra & Gamal \\
\hline Daun (kg/56 hari) & $0,62^{\mathrm{ns}}$ & 0,50 \\
\hline Batang (kg/56 hari) & $0,49^{\text {ns }}$ & 0,35 \\
\hline Kulit (Kg) & $0,19^{\text {ns }}$ & 0,09 \\
\hline Batang tanpa kulit $(\mathrm{Kg})$ & $0,28^{\text {ns }}$ & 0,24 \\
\hline Daun dan batang $(\mathrm{Kg})$ & $1,08^{\text {ns }}$ & 0,90 \\
\hline Diameter cabang (mm) & $45,14^{\mathrm{a}}$ & $63,10^{6}$ \\
\hline Panjang cabang (cm) & $717,26^{\mathrm{ns}}$ & 744,18 \\
\hline
\end{tabular}

Hasil pengamatan produksi segar baik kaliandra dan gamal tidak berbeda nyata untuk penanaman pada areal pematang sawah. Diameter cabang gamal memiliki diameter cabang yang lebih besar dibandingkan diameter cabang gamal. Menurut Mustofa (2009) Batang gamal berukuran kecil hingga sedang, tingginya dapat mencapai $10-12 \mathrm{~m}$, sering bercabang dari dasar dengan diameter basal mencapai $50-70 \mathrm{~cm}$. Kulit batang halus dengan warna bervariasi, dari putih abu-abu kemerah tua-coklat. Sedangkan untuk kaliandra menurut Kartikasari (2001) adalah pohon kecil bercabang yang tumbuh mencapai tinggi maksimum $12 \mathrm{~m}$ dan diameter batang maksimum 20 $\mathrm{cm}$. Kulit batangnya berwarna merah atau abu-abu yang tertutup oleh lentisel kecil, pucat berbentuk oval. Ke arah pucuk batang cenderung bergerigi, dan pada pohon yang batangnya coklat-kemerahan, ujung batangnya bisa berulas merah.

Menurut Kartikasari (2001) Calliandra calothyrsus dapat ditanam dalam satu atau beberapa barisan di sepanjang batas lahan petani atau pada tanggul kontur, gulu dan teras atau tempat-tempat yang serupa. Dibanyak tempat, lokasi seperti ini dapat dimanfaatkan untuk menanam kaliandra tanpa menimbulkan dampak negatif terhadap tanaman pangan didekatnya. Dalam barisan, pohon ditanam dengan jarak $40-50 \mathrm{~cm}$. Hasilnya akan beragam bergantung pada iklim, kesuburan tanah, dan faktorfaktor lainnya. Tanaman gamal mempunyai produksi daun yang cukup melimpah selama musim penghujan.

Hasil data produksi daun dan batang pada tanaman kaliandra dan gamal pada Tabel 1 dapat diketahui bahwa proporsi daun: batang pada rasio 57\%: 45\%. Ella et al. (1991) menyatakan bahwa peningkatan umur tanaman diikuti dengan peningkatan pada produksi dan proporsi ranting, serta penurunan proporsi daunnya. Penurunan pada proporsi daun dan ranting akan berhubungan dengan peningkatan kandungan dinding sel (Djuned et al., 2005), selanjutnya Mei et al. (2015) menjelaskan bahwa setiap peningkatan umur pemotongan juga disertai dengan peningkatan produksi daun, ranting dan total tanaman. Kedua tanaman kaliandra dalam penelitian ini memiliki umur tanamn selama lima tahun dengan masa pemanenan setiap 56-60 hari, sehingga proporsi daun dan batang dari kedua tanaman ini berkisar 50-60\%.

\section{Kualitas Nutrisi Kaliandra dan Gamal dari Bagian Tanaman yang Berbeda}

Tanaman pakan ternak yang dipanen pada umur pemotongan yang lama akan mempengaruhi kualitas dari hijauan, selain produktivitas tanaman, kualitas hijauan juga ditentukan dari kandungan nutrisi tanaman, beberapa diantaranya adalah kandungan bahan kering (BK), bahan organik (BO), serat kasar (SK) dan protein kasar (PK). Kandungan nutrisi dan nilai kecernaan bahan kering $(\mathrm{KcBK})$ dan bahan organik (KcBO) disajikan pada Tabel 2. Berdasarkan Tabel 2. Nilai kecernaan daun gamal dan kaliandra hampir sama yakni $45 \%$, akan tetapi pada bagian kulit kayu baik kaliandra dan gamal memiliki nilai kecernaan yang tinggi antara 59-60\%. Perbedaan nilai kecernaan pada bagian daun dan kulit kayu juga dipengaruhi dari komposisi nutrisi yang lain pada bagian tanaman tersebut, misalnya kandungan protein dan serat. Menurut Firsoni dan Ansori (2015) daun gamal memiliki protein kasar 23,5\%, lemak kasar $3,1 \%$ serat kasar $16,77 \%$, Ca $1,3 \%$, dan $\mathrm{P} 0,18 \%$, sedangkan daun kaliandra memiliki protein kasar $29,28 \%$, lemak kasar 5,55\%, dan serat kasar 9,44\% (Novia et al., 2015).

Kecernaan bahan kering merupakan salah satu indikator untuk menentukan kualitas ransum. Semakin tinggi kecernaan bahan kering maka semakin tinggi pula peluang nutrisi yang dapat dimanfaatkan ternak untuk pertumbuhannya (Afriyanti, 2008). Sedangkan kecernaan bahan organik menggambarkan ketersedian nutrient dari pakan. Kecernaan bahan organik dalam saluran pencernaan ternak meliputi kecernaan zat-zat makanan berupa komponen bahan organik seperti karbohidrat, protein, lemak dan vitamin. Bahan-bahan organik yang terdapat dalam pakan tersedia dalam bentuk tidak larut, oleh karena itu diperlukan adanya proses pemecahan zat-zat tersebut menjadi zat-zat yang mudah larut. Hasil evaluasi kecernaan bahan kering dan bahan organic pada Tabel 2. bahwa ratarata kandungan $\mathrm{BK}$ dan $\mathrm{BO}$ dari semua bagian morfologi tanaman kaliandra dan gamal hampir sama pada kisaran 80-90\%, untuk kandungan PK tertinggi pada daun gamal sebanyak $24,68 \%$ dan pada bagian kulit kayu sebanyak 15,84\%. 
Tabel 2. Kualitas Nutrisi dan Kecernaan bagian tanaman kaliandra dan gamal*

\begin{tabular}{lcccc}
\hline \multirow{2}{*}{\multicolumn{1}{c}{ Parameter pengamatan }} & \multicolumn{3}{c}{ Daun } & \multicolumn{2}{c}{ Kulit Kayu } \\
\cline { 2 - 5 } & Kaliandra & Gamal & Kaliandra & Gamal \\
\cline { 2 - 5 } & 88,65 & 90,26 & 91,42 & 90,17 \\
\hline Bahan Kering (\% BK) & 94,08 & 90,68 & 92,7 & 90.97 \\
Bahan Organik (\% BO) & 20,49 & 24,68 & 16,76 & 15,84 \\
Protein Kasar (\% PK) & 3,44 & 15,78 & 9,4 & 8,88 \\
Lemak Kasar (\% LK) & 12,93 & 15,70 & 24,05 & 33,07 \\
Serat Kasar (\% SK) & 32,81 & 37,99 & 51,25 & 54,61 \\
Kecernaan bahan kering (\%KcBK) & 45,19 & 45,16 & 60,48 & 59,49 \\
Kecernaan bahan organik (\%KcBO) & * & &
\end{tabular}

Rataan kecernaan bahan organic pada penelitiaan hampir sama diduga karena kecernaan bahan kering pada penelitiaan ini juga menunjukan kecernaan bahan kering yang hampir sama pada semua bagian tanaman. Sesuai dengan pendapat Sutardi (1980), degradasi bahan organik erat kaitannya dengan degrades bahan kering, karena sebagian bahan kering terdiri dari bahan organik. Darwis (1988) menyatakan bahwa penurunan kecernaan bahan kering mengakibatkan kecernaan bahan organik menurun atau sebaliknya. Dijelaskan lebih lanjut oleh Crampton dan Harris (1969) bahwa kecernaan makanan tergantung pada aktifitas mikroorganisme rumen karena mikroorganisme rumen berperan dalam proses fermentasi, sedangkan aktifitas mikroorganisme rumen itu sendiri dipengaruhi oleh zat-zat makanan yang terdapat dalam bahan makanan.

Kecernaan bahan kering dan bahan organik pada bagian kulit lebih tinggi dibandingkan nilai kecernaan pada bagian daun dikarenakan bagian kayu yang dipanen memiliki diameter 45-60 $\mathrm{mm}$ dan pada bagian batang yang muda, selanjutnya dikelupas pada bagian kulitnya saja. Kartikasari (2001) juga menjelaskan bahwa dengan sistem pangkas dan angkut, pohon kaliandra dibiarkan tumbuh sampai ketinggian tertentu kemudian dipangkas. Kemudian tunas baru dipangkas secara berkala dan diberikan kepada ternak yang berada di tempat lain. Ketika hijauan ternak sangat banyak dan tumbuh sangat cepat, ternak akan memakan cabang-cabang yang hijau dan lunak yang diameternya mencapai sekitar 1 $\mathrm{cm}$. Namun ketika tanaman tumbuh lebih lambat, cabang menjadi berkayu dan diameternya lebih kecil, dan ternak hanya akan memakan cabang-cabangyang diameternya lebih kecil dari $0,4 \mathrm{~cm}$. Setelah ternak memakan daun dan ranting kecil (bagian yang bisa dimakan), sisa batangnya dapat dikeringkan dan digunakan sebagai kayu bakar. Untuk mengoptimumkan nilai gizi hijauan ternak, pemangkasan sebaiknya dilakukan jika tunas baru sudah mencapai ketinggian sekitar $100 \mathrm{~cm}$.Saat itu, bagian yang dapat dimakan mencapai 50-60\% dari biomassa total. Umumnya cara pemangkasan seperti ini dapat dilakukan empat sampai enam kali setahun. Selama musim hujan, kaliandra dapat dipangkas setiap enam minggu sekali tanpa mengalami penurunan produktivitas dan kualitas.
Penggunaan legume sebagai pakan tunggal pada ternak ruminansia, perlu adanya suatu penelitian, mengingat ada beberapa kendala penggunaan legume sebagai pakan ternak. Kendala penggunaan Kaliandra sebagai pakan tunggal adalah ketersediaan nutrien menjadi rendah karena Kaliandra mengandung tannin yang dapat melindungi protein dari proses perombakan oleh mikroba rumen dan proses enzimatis dalam usus, sehingga dapat menurunkan pemanfaatan nutrien oleh ternak. Tangendjaja et al. (1992) melaporkan bahwa kandungan tanin dalam Kaliandra sebesar 1,5 hingga 11,3 persendan memiliki daya cerna bahan keringsecara in vitro berkisar antara 35 hingga 53persen. Nilai ini lebih rendah dibandingkan dengan tanaman leguminosa lainnya, seperti Lamtoro, Gamal, dan Sengon. Hasil penelitian Tangendjaya ini mendukung hasil penelitian yang menunjukkan kecernaan baik kaliandra dan gamal sebagai pakan tunggal pada ternak ruminansia berkisar anatara $45-60 \%$. Hasil penelitian ini menunjukkan bahawa kecernaan kedua bahan pakan tersebut tidak terlalu tinggi, akan tetapi menurut ARC (1984) besarnya kecernaan pakan pada ternak ruminansia sekitar $65 \%$ tergantung dari mikroba rumen. Kecernaan juga sangat tergantung pada komposisi zat makanan yang terkandung dalam pakan dan laju aliran pakan meninggalkan rumen (Ørskov dan Ryle, 1990). Hasil kecernaan bahan organik sejalan dengan kecernaan bahan kering,hal ini karena kadar bahan organik terdapat dalam bahan kering sehingga hasil kecernaan bahan organik sejalan dengan kecernaan bahan kering (Trisnadewi dan Cakra, 2015).

\section{KESIMPULAN}

Evaluasi kualitas nutrisi dan kecernaan pada bagian morfologi tanaman kaliandran dan gamal dapat disimpulkan bahwa bagian kulit kayu lebih tinggi dibandingkan bagian daun, sedangkan untuk produksi tanaman tidak berbeda nyata antara kedua tanaman tersebut .

\section{DAFTAR PUSTAKA}

Afriyanti, M. 2008. Fermentabilitas dan kecernaan in vitro ransum yang diberi kursin bungkil biji jarak pagar (Jatropha curcas L.) pada ternak 
sapi dan kerbau. Skripsi. Fakultas Peternakan. Institut Pertanian Bogor. Bogor.

Andrew, S. 1994. Tropical Feeds and Feeding Systems. First FAO electronic conference on tropical feeds and feeding systems. http:// http://www.fao.org/livestock/agap/frg/ECONF9 5/ECONF95.htm. Diakses pada tanggal 4 Februari 2017.

AOAC. 1990. Official Methods of Analysis of The Association of Agriculture Chemist A.O.A.C, Washington D.C

ARC. 1984. The Nutrient Requirement Of Ruminant Livestock. England (UK): Commonwealth agricultural Bureaux, Slough.at two cutting heights an interval. Livestock Research Centre. Malaysia. Cetakan ke-3. Gadjah Mada University Press. Yogyakarta.

Blümmel, M., H. Steingab, and K.. Becker. 1997. The Relationship between invitro gas production, invitro microbial biomass yield and ${ }^{15} \mathrm{~N}$ incorporation and its implications for prediction of voluntary feed intake of roughages. British Journal of Nutrition 77(6): 911-921.

Crampton, E.E. And L.E. Harris. 1969. Applied Animal Nutrition $2^{\text {nd }}$ ed. L. H. Freeman and Co. San Francisco.

Darwis, A.A., T. Budasor, L., Hartato dan M. Alisyahbana, 1988. Studi potensi limbah lignosellulosa di indonesia. PAU Bioteknologi IPB. Bogor.

Djuned, H., Mansyur dan H.B. Wijayanti. 2005. Pengaruh umur pemotongan terhadap kandungan fraksi serat hijauan murbei (Morus indica $L$. Var. Kanva-2). Seminar Nasional Teknologi Peternakan dan Veteriner. Jakarta.

Ella, A., G. J. Blair, and W. W. Stur. 1991. Effect of age of forage tree legumes at the first cutting on subsequent production. Tropical Grasslands 25: 275-280.

Elevitch, C.R and J.K. Francis 2006. Species profiles for island agroforestry. http://www.traditionaltree.org. Diakses pada tanggal 4 Februaari 2017.

Firsoni dan D. Ansori. 2015. Manfaat Urea Molasses Multinutrient Blok (UMMB) yang Mengandung Tepung Daun Glirisidia (Gliricidia sepium) secara In-vitro. Jurnal Ilmiah Aplikasi Isotop dan Radiasi 11(02): 161-170.

Hartadi, H., S. Reksohadiprodjo and A.D. Tillman. 1993. Tabel komposisi pakan untuk indonesia. Gadjah Mada University Press. Yogyakarta.

Karda, I.W. 2011. Kaliandra Merah Dalam Sistem Pertanian Konservai peluang, Kendala dan Solusi. Udayana University Press. Bali.

Kartikasari, S.N. 2001. Produksi dan Pemanfaatan Kaliandra (Calliandra calothirsus). Pedoman Lapangan.Winrock International dan the Taiwan Forestry Research Institute. Berkolaborasi dengan Pusat Penelitian dan Pengembangan
Kehutanan, Department Kehutanan, Indonesia, the Overseas Development.

Mei, V.S., H. Sudarwati dan Hermanto. 2013. Pengaruh Umur Pemotongan Terhadap Produktivitas Gamal (Gliricidia sepium). Jurnal Ilmu-Ilmu Peternakan 23 (2):25-35.

Menke, K.H. dan H. Steingass. 1988. Estimation of the energetic feed value obtained from chemical analysis and in vitro gas production using rumen fluid. Animal Research Development 28: 499503.

Mulyana, A., Sumarta, T. Hidayat dan Karma. 2006. Produktivitas Beberapa Varietas Kaliandra (Calliandra calothyrsus) sebagai Hijauan Pakan Ternak. Temu Teknis Nasional Tenaga Fungsional Pertanian. Pusat Penelitian dan Pengembangan Peternakan.

Mustofa. 2009. Informasi Spesies Gamal (Gliricidia sepium). http: //www. plantamor. Com. Diakses pada tanggal akses 4 Juli 2009.

Natalia, H., D. Nista, dan S. Hindrawati. 2009. Keunggulan gamal sebagai pakan ternak. http://bptusembawa. net/v1/data/download/ 20110928094232.pdf. Diakses tanggal 4 Februaari 2017.

Novia, Q., Y, Retnani. dan I.G. Permana. 2015. Kecernaan Bahan Kering dan Bahan Organik Wafer Daun Kaliandra Pada Kambing Peranakan Etawah. Jurnal Pertanian Agros 17(01): 113-120.

Orskov, E.R. 1992. Protein Nutrition in Ruminant. Academic Press Ltd. London.

Ørskov, E.R. 2000. New concepts of feed evaluation for ruminants with emphasis on roughages and feed intake. Asian-Australasian Journal Animal Science 13: 128-136.

Ørskov, E.R. and Ryle M., 1990. Energy Nutrition in Ruminants. Elsevier Applied Science, London (UK). pp. 133-144

Salawu, M.B., T. Acamovic, C.S. Stewart and R.L. Roothaert. 1999. Composition and degradability of different fractions of Calliandra leaves, pods, and seed. Animal Feed Science and Technology 77. 181-199.

Sutardi, T. 1980. Landasan Ilmu Nutrisi Jilid 1. Institut Pertanian Bogor. Bogor

Tangendjaja, B., E. Wina, B. Palmer. dan T. Ibrahim. 1992. Kaliandra dan pemanfaatannya. ACIAR dan Balitnak.

Trisnadewi, A.A.A.S dan I.G.L.O. Cakra. 2015. Kecernaan in vitro Tanaman Kaliandra (Calllandra calothyrsus) Berbungan Merah dan Putih. Pastura 5(01): 39-41.

Wong, C.C. 2012. Assessment of gliricidia sepium provenance Retalhuleu for forage production at two cutting heights an interval. Livestock Research Center. Malaysia. 